\title{
Long-term monitoring of black turtles Chelonia mydas at coastal foraging areas off the Baja California Peninsula
}

\author{
Melania C. López-Castro1,2, Volker Koch ${ }^{3,4, *}$, Antonio Mariscal-Loza ${ }^{3}$, \\ Wallace J. Nichols ${ }^{5,6}$ \\ ${ }^{1}$ Grupo Tortuguero de Las Californias, La Paz, Baja California Sur 23060, Mexico \\ ${ }^{2}$ Centro de Investigaciones Biológicas del Noroeste, La Paz, Baja California Sur 23090, Mexico \\ ${ }^{3}$ Departamento de Biología Marina, Universidad Autónoma de Baja California Sur, La Paz, \\ Baja California Sur 23080, Mexico \\ ${ }^{4}$ Investigación para la Conservación y el Desarrollo A.C. (INCODE A.C.), La Paz, Baja California Sur, Mexico \\ ${ }^{5}$ The Ocean Conservancy, Davenport, California 95017, USA \\ ${ }^{6}$ Department of Herpetology, California Academy of Sciences, San Francisco, California 94118, USA
}

\begin{abstract}
Monthly in-water monitoring was conducted at 5 foraging areas off the Baja California Peninsula, Mexico, from 2001 to 2006 to assess black turtle population status. Turtles were captured with entanglement nets, size (straight carapace length, SCL) and weight of each individual were recorded and turtles were tagged on both rear flippers. A total of 1238 turtles were captured, involving $6309 \mathrm{~h}$ of effort. Of this total, 937 ind. were marked and 155 were recaptured. SCL ranged from 30 to $95.5 \mathrm{~cm}$; immature turtles accounted for $>94 \%$ of the total catch and were dominant at all sites. However, size class distribution varied among sites, and turtles from the Gulf of California were significantly larger than those caught in the Pacific. Catch per unit of effort (defined as the number of turtles caught per $100 \mathrm{~m}$ of net soaking for $24 \mathrm{~h}$ ) varied from 1.79 at Bahía Magdalena to 17.35 at

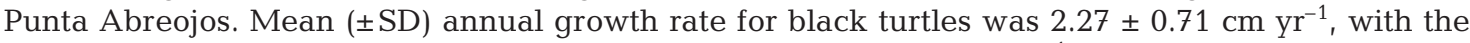
lowest and highest growth rates in Bahía Magdalena $\left(1.37 \pm 0.71 \mathrm{~cm} \mathrm{yr}^{-1}\right)$ and Laguna Ojo de Liebre $\left(3.05 \pm 2.23 \mathrm{~cm} \mathrm{yr}^{-1}\right)$, respectively. Lack of recaptures from adjacent sites and multiple recaptures of specimens at the site of origin over several years indicate a low connectivity among foraging areas and a high site fidelity. Hence, strengthening local protection is imperative to the recovery of black sea turtle populations.
\end{abstract}

KEY WORDS: Black turtle $\cdot$ East Pacific green turtle $\cdot$ Chelonia mydas $\cdot$ Population ecology $\cdot$ Northwest Mexico $\cdot$ Growth $\cdot$ Size distribution $\cdot$ CPUE $\cdot$ Population status

\section{INTRODUCTION}

One of the main problems in sea turtle conservation has been the lack of understanding of their population status on foraging grounds (Seminoff et al. 2003). Data on population size, size-frequency distribution, habitat use and movement, time of residence, individual growth rate and the contribution of different nesting populations to the stocks on the foraging grounds are essential as they provide important insights into population trends and are used to evaluate and inform conservation strategies (Chaloupka \& Musick 1997). However, little has been done as yet to assess the status of sea turtle populations on their foraging areas in the eastern Pacific due to the labor- and cost-intensive long-term work required (Nichols 2003). 
Black turtles, or East Pacific green turtles Chelonia mydas, are currently listed as endangered on the IUCN Red List (Hilton-Taylor 2000). The dramatic population decline of olive ridley and black turtles was mainly caused by the overexploitation of eggs, leather and meat from the 1950s to the 1970s (Groombridge \& Luxmoore 1989), when Mexico alone contributed over $50 \%$ to the world's sea turtle catch (Márquez 1990). In an effort to recover all sea turtle populations, the Mexican government banned their harvest and trade in 1990 by presidential decree (Diario Oficial de la Federación 1990) and implemented programs to protect sea turtles on their nesting beaches. While nesting beach protection has been largely successful in the past decades, high mortality rates due to bycatch and illegal harvest are still reported from foraging areas in northwest Mexico, especially of black and loggerhead turtles (Gardner \& Nichols 2001, Nichols 2003, Koch et al. 2006, Peckham \& Nichols 2006). As a result, population recovery of the black turtle (measured as the number of nesting females on the beaches in Michoacán) has been slow and it has become clear that nesting beach protection alone may not be sufficient to ensure population recovery (Koch et al. 2006, 2007). The Baja California Peninsula provides important foraging and nursery areas and is considered a key region for sea turtle conservation (Cliffton et al. 1982, Koch et al. 2002, 2007, Nichols 2003, Seminoff et al. 2003). However, many aspects of the black turtle aggregations on the East Pacific foraging grounds still remain unknown, such as the size distribution in different areas, population density and total abundance, individual growth and residence times of juveniles and connectivity between foraging areas.

For these reasons, the Grupo Tortuguero Network was founded in 1999 and began community-based black turtle monitoring in 2001 at several coastal foraging areas to provide necessary information to create adequate strategies for their recovery in the region and strengthen local protection (Delgado \& Nichols 2005).

The overall objectives of the present study were to gather data on the population status of the black turtle in foraging areas off the Baja California Peninsula and provide baseline information for the development of informed conservation strategies. Specifically, we quantified the following over a 5 yr monitoring period: (1) population size distribution and percentage of immature turtles at each site; (2) body condition index and mean annual growth rate as indicators of popu- lation health; and (3) catch per unit effort (CPUE) as a proximate measure of black turtle abundance.

\section{MATERIALS AND METHODS}

Study area. The study was conducted at 5 different foraging areas along the Baja California Peninsula (Fig. 1). We present the results from 4 sites located on the Pacific coast of the peninsula where monitoring has been relatively constant over the last 5 yr: Laguna Ojo de Liebre (LOL), Punta Abreojos (PAO), Laguna San Ignacio (LSI) and Bahía Magdalena (BMA). Additionally, we present data from a site located in the Gulf of California at El Pardito (EPA), where monitoring began in September 2005.

Laguna Ojo de Liebre: LOL is located on the Pacific coast near the border between Baja California Sur and Baja California. It is part of the El Vizcaino Biosphere reserve and extends from $27^{\circ} 35^{\prime}$ to $27^{\circ} 55^{\prime} \mathrm{N}$ and $113^{\circ} 58^{\prime}$ to $114^{\circ} 10^{\prime} \mathrm{W}$. It is characterized by a dry climate and cold air temperatures in winter. Maximum water temperatures range from 20 to $26^{\circ} \mathrm{C}$ in the summer and minimum temperatures from 12 to $20^{\circ} \mathrm{C}$ in the winter. The channels reach a depth of up to $16 \mathrm{~m}$. Zostera marina and several species of benthic macroalgae are abundant in the lagoon (Águila-Ramírez 1998). It is one of the 4 major breeding grounds for the East Pacific gray whale population.

Punta Abreojos (Estero Coyote): PAO is also located on the Pacific coast of the peninsula, and is also part of the El Vizcaino Biosphere reserve. The site consists of a small and shallow coastal lagoon which lies northeast

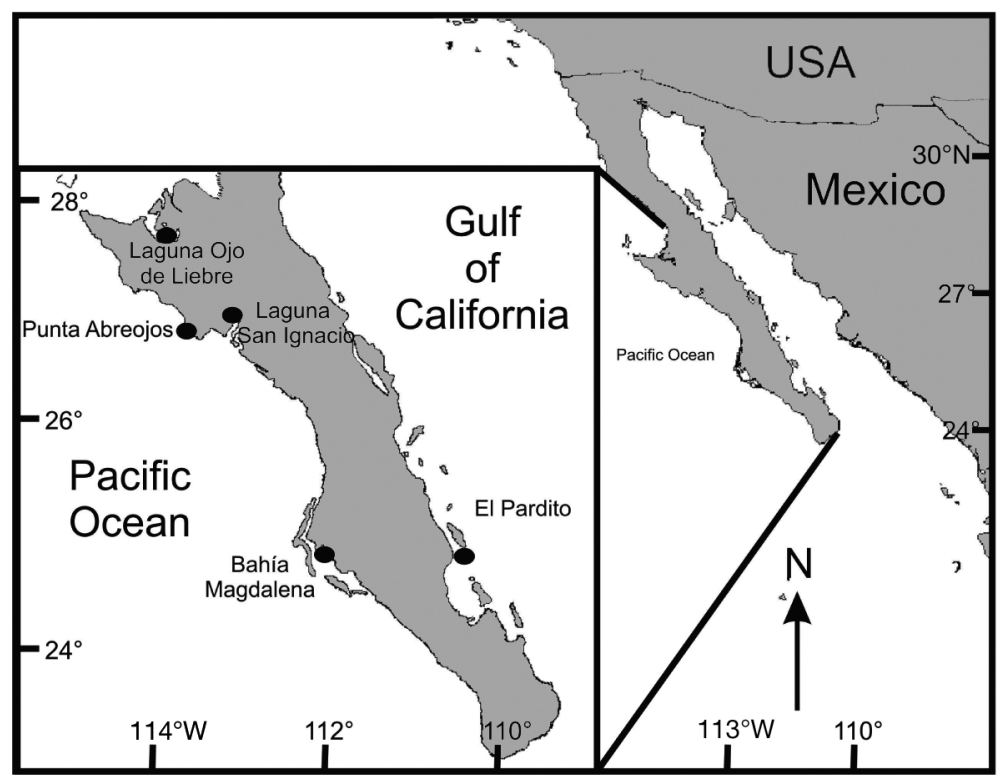

Fig. 1. Study area. The 5 monitoring sites along the Baja California Peninsula are marked with black circles 
of Punta Abreojos, a fishing community exploiting lobster, abalone and finfish. It is relatively pristine, lined by mangrove forests and large beds of seagrass and algae abound in the lagoon (Nichols 2003). The maximum average water temperature is $26^{\circ} \mathrm{C}$ during summer and the minimum average temperature is $17^{\circ} \mathrm{C}$ during winter. Black sea turtles are very abundant in this area.

Laguna San Ignacio: LSI is located on the Pacific side, close to Estero Coyote, between $26^{\circ} 43^{\prime}$ to $26^{\circ} 58^{\prime} \mathrm{N}$ and $113^{\circ} 08^{\prime}$ to $113^{\circ} 16^{\prime} \mathrm{W}$. It is also part of El Vizcaino Biosphere reserve. Mean annual temperature ranges between 18 and $26^{\circ} \mathrm{C}$. The lagoon has an extension of approximately 17500 ha. It has extensive seagrass beds and mangrove swamps (Nichols 2003). Besides providing shelter to black sea turtles, the lagoon is also important for the reproduction of gray whales, as well as several species of migratory seabirds. The monitoring site was located at the head of the lagoon.

Bahía Magdalena: BMA is located on the Pacific coast of Baja California at $24^{\circ} 15^{\prime}$ to $25^{\circ} 20^{\prime} \mathrm{N}$ and $111^{\circ} 30^{\prime}$ and $112^{\circ} 15^{\prime} \mathrm{W}$; the lagoon is sheltered by 2 barrier islands, Isla Margarita and Isla Magdalena. Seasonal upwelling outside the mouth and extensive mangrove forests and seagrass beds make BMA a highly productive ecosystem (Maeda-Martínez et al. 1993). Sea surface temperature varies seasonally, reaching a maximum of $28^{\circ} \mathrm{C}$ in September and a minimum of $19^{\circ} \mathrm{C}$ in March (Lluch-Belda et al. 2000). The inner channels of the bay provide shallow protected areas of mangrove lagoons for juvenile black sea turtles while the rocky areas near the mouth of BMA provide food for subadult and adult turtles (López-Mendilaharsu et al. 2005)

El Pardito: Located on the Gulf of California coast $\left(24^{\circ} 51^{\prime} 10^{\prime \prime} \mathrm{N}, 110^{\circ} 34^{\prime} 52^{\prime \prime} \mathrm{W}\right), \mathrm{EPA}$ is a small islet between Islas San José and San Francisquito, north of Bahía de La Paz (Fig. 1). It is part of an island complex within the Gulf of California which has been under protection since 1978. Water temperature varies between 18 and $30^{\circ} \mathrm{C}$ in winter and summer, respectively (Rengstorf 2007). Monitoring took place in Ensenada La Amortajada, on the southeast coast of Isla San Jose.

Turtle capture and measurement. Between August 2001 and November 2006, black turtles were captured once every month in shallow areas $(<8 \mathrm{~m}$ depth) of each monitoring site using entanglement nets (mesh size $=50 \mathrm{~cm}$ stretched) with very little weight on the lead line, so turtles that were caught could come up to the surface to breathe (Koch et al. 2007). Net length varied between sites due to different oceanographic conditions: at LOL, a $100 \mathrm{~m}$ length net was used; at PAO, 2 nets of 90 and $60 \mathrm{~m}$ length were used; at LSI,
2 nets of 111 and $64 \mathrm{~m}$ length were used; at BMA, 2 nets of 100 and $140 \mathrm{~m}$ were used; and at EPA, 1 net of $270 \mathrm{~m}$ length was used. Net height was $8 \mathrm{~m}$ in all cases. Nets were set during both day and night over a period of 10 to $24 \mathrm{~h}$, depending on weather conditions and permit regulations. Nets were monitored constantly to avoid drowning of captured turtles. Upon capture, turtles were taken to shore where they were weighed, measured and tagged. All turtles were released at the site of initial capture immediately after the sampling was completed $(<24 \mathrm{~h})$ to avoid recapturing the same individual.

Straight carapace length (SCL) was measured from the nuchal notch to the posterior end of the rear marginal scutes using a forester caliper $( \pm 0.1 \mathrm{~cm})$. Mass was determined to the nearest pound using a $500 \mathrm{lb}$ spring balance, and converted to $\mathrm{kg}$. Each turtle was tagged using Inconel tags (National Band and Tag) on each rear flipper (usually between the first and second large proximal scales).

A body condition index ( $\mathrm{BCI}=$ body mass $\times$ $10000 / \mathrm{SCL}^{3}$ ) was calculated to evaluate the relative 'fatness' of captured turtles (Bjorndal et al. 2000).

Size distribution of individuals was compared among foraging areas to identify significant differences using a Kruskal-Wallis test (Zar 1999). To estimate the proportion of juveniles among all turtles caught in each area, we used the average size of nesting females registered at nesting areas of Michoacán (77.3 cm SCL) as an index of size at maturity (Koch et al. 2006, 2007), since most black turtles originate from Michoacán nesting beaches (Esquivel Bobadilla 2007).

CPUE. One unit of effort was defined as $100 \mathrm{~m}$ of net being in the water for $24 \mathrm{~h}$. Effort was calculated for each sampling as follows (modified after Koch et al. 2007): $\mathrm{CPUE}=($ soaking time $/ 24 \times$ net length $/ 100) /$ no. of turtles caught.

We calculated CPUE for each site and sampling occasion, except in cases where monitoring was not possible due to weather conditions and/or permit restrictions (e.g. gray whale season at LSI and LOL). In the case where 2 nets were used in the same monitoring event, CPUE was calculated for each net separately.

Growth. Annual growth rate was calculated from data collected from recaptured organisms as follows: $\left(\mathrm{SCL}_{\text {final }}-\mathrm{SCL}_{\text {initial }}\right) /$ recapture interval; where the recapture interval is in years (as used by Seminoff et al. 2002). In all cases, only recaptured turtles that were at large for more than 11 mo were considered.

Statistical analysis. Each group of data was tested with the Shapiro-Wilkinson test for normality and Levene's test for homoscedasticity (Zar 1999). In all cases, $\alpha=0.05$ was used. Analyses were performed using Systat 11 software. Comparisons of CPUE, SCL and 
BCI were made using a 1-way ANOVA or the nonparametric equivalent Kruskal-Wallis test when ANOVA assumptions were not met. Whenever significant differences were detected, we used Tukey's honestly significant difference test for multiple comparisons for the parametric cases, or a Kruskal-Wallis 2-sample ranking test (non-parametric) to show, in both cases, the formation of homogeneous groups (Zar 1999).

\section{RESULTS}

During the 5 yr of monitoring, a total of 1243 turtles were caught. All were black turtles, except for 3 hawksbill (2 at BMA, 1 at EPA) and 2 loggerhead turtles (at LOL) that were not included in the analyses. Of the 1238 black turtles, 937 were tagged (301 turtles were not tagged because monitoring teams ran out of tags), and a total of 155 turtles were recaptured at least once (Table 1). None of the recaptured turtles had been previously tagged at another foraging area, even though some of the sampling sites are relatively close to each other; for example, LSI and PAO are approximately $40 \mathrm{~km}$ apart.

\section{Size class distribution and mass}

SCL varied between 30 and $95.5 \mathrm{~cm}$, and size class distribution differed among sites. Sizes at PAO ranged from 30 to $95.5 \mathrm{~cm} \mathrm{SCL}$, presenting the widest size range of all sites (Fig. 2, Table 2). ANOVAs showed significant size differences among sites (Kruskal-Wallis, $K=117.272$, p $<0.001$; Table 3); turtles at LSI were significantly smaller in SCL than at other sites and those caught at EPA were significantly larger than those from all other sites and had the highest percentage of adult-sized turtles. In general, juveniles accounted for $95 \%$ of all turtles caught; only 60 ind. were considered adult-sized (Fig. 2). The average mass of

Table 1. Chelonia mydas. Netting effort and number of turtles caught, tagged and recaptured at the 5 sampling sites. Monitoring began in 2001 at all sites except El Pardito, where it began in 2005

\begin{tabular}{|lcccc|}
\hline Site & $\begin{array}{c}\text { Total net } \\
\text { hours }\end{array}$ & $\begin{array}{c}\text { Total no. } \\
\text { caught }\end{array}$ & $\begin{array}{c}\text { Total no. } \\
\text { tagged }\end{array}$ & $\begin{array}{c}\text { Total no. } \\
\text { recaptured }\end{array}$ \\
\hline Laguna Ojo de Liebre & 744 & 150 & 124 & 22 \\
Punta Abreojos & 1580 & 633 & 501 & 80 \\
Laguna San Ignacio & 1392 & 223 & 141 & 25 \\
Bahía Magdalena & 2449 & 173 & 113 & 27 \\
El Pardito & 144 & 59 & 59 & 1 \\
Total & 6309 & 1238 & 937 & 155 \\
\hline
\end{tabular}

individual turtles ranged from 7.3 to $108.9 \mathrm{~kg}$. Similar to the SCL results, the average mass of turtles was highest at EPA and smallest at LSI (Table 2).

\section{Body condition index}

We used Grubbs' test (Grubbs 1969) to eliminate 15 outliers due to errors in recording size (SCL) and/or mass (Koch et al. 2007). Estimates of BCI ranged from 0.67 to 2.30 (Table 2). One-way ANOVA showed that the BCI of turtles was significantly smaller in LSI than at all other sites, which did not differ from each other (Table 4a). When comparing BCI between years at each site (Fig. 3), few significant differences were found and no clear trend was visible, except possibly at LSI, where BCI seemed to increase toward the end of the sampling period (Fig. 3, Table 4). The seasonal comparison showed differences at all sites except for LOL. Turtles were generally fatter during the summer months than in winter (Fig. 3).

Throughout the 5 yr of monitoring, only 29 turtles ( $2.3 \%$; data not shown) appeared to be sick, with low body mass, high numbers of external parasites or other apparent external manifestations of disease. There were some turtles with missing flippers but with a good BCI and a healthy appearance. No cases of fibropapillomatosis were reported.

\section{Recapture intervals}

A total of 155 black turtles $(12.47 \%)$ were recaptured during the $5 \mathrm{yr}$ of monitoring (LOL $=23,14.83 \%$; $\mathrm{PAO}=79,50.96 \% ; \mathrm{LSI}=25,16.12 \% ; \mathrm{BMA}=27$, $17.41 \% ; \mathrm{EPA}=1,0.64 \%$ ). Recapture intervals ranged from 1 mo to 4 yr 11 mo. In most cases, turtles were recaptured only once (139 ind.: LOL $=21$; PAO $=70$; LSI $=23$; $\mathrm{BMA}=24$; EPA $=1$ ); however, 13 turtles were recaptured twice (PAO = 9, $\mathrm{LSI}=2, \mathrm{LOL}=1, \mathrm{BMA}=1), 1$ turtle 3 times (LOL), 1 turtle 4 times (BMA) and 1 turtle 5 times (BMA). From our recapture data, it seems that turtles remain yearround in their foraging area.

Rates of recapture varied across years; however, the percentage remained low. Overall, there were 15 recaptures in the first year (August 2001 to July 2002, 7.42\%); 56 in the second year (August 2002 to July 2003, 11.02\%); 29 in the third year (August 2003 to July 2004, 4.71\%); 41 in the fourth year (August 2004 to July $2005,5.62 \%)$; and 36 in the fifth year (August 2005 to December 2006, 


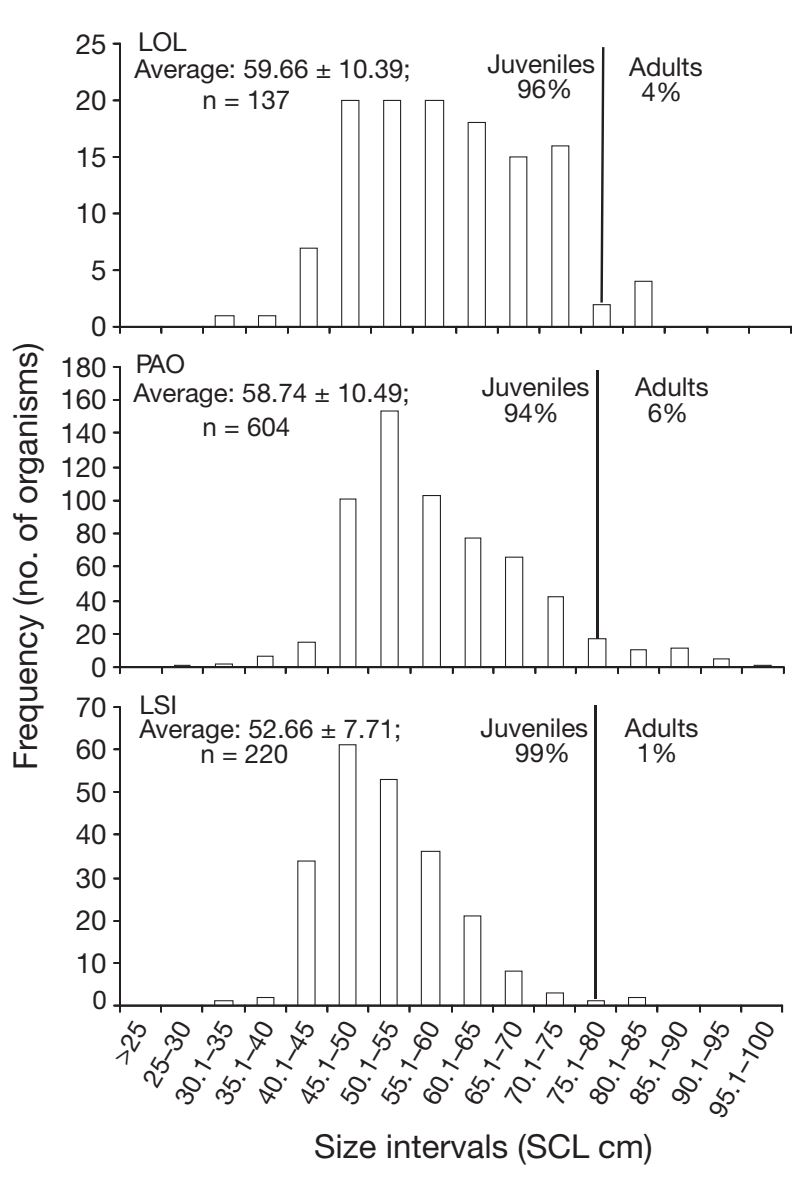

$3.85 \%)$. No recaptures from sampling sites other than the original capture site were registered.

\section{Annual growth rate}

SCL at time of first capture ranged from 43 to $82.3 \mathrm{~cm}$ $($ mean $\pm \mathrm{SD}=57.66 \pm 9.06 \mathrm{~cm})$. Mean recapture interval was $24 \pm 12 \mathrm{mo}$. Growth rates ranged from $0 \mathrm{~cm} \mathrm{yr}^{-1}$ (a $60 \mathrm{~cm}$ SCL turtle at large for $23 \mathrm{mo}$ at PAO) to $7.6 \mathrm{~cm}$
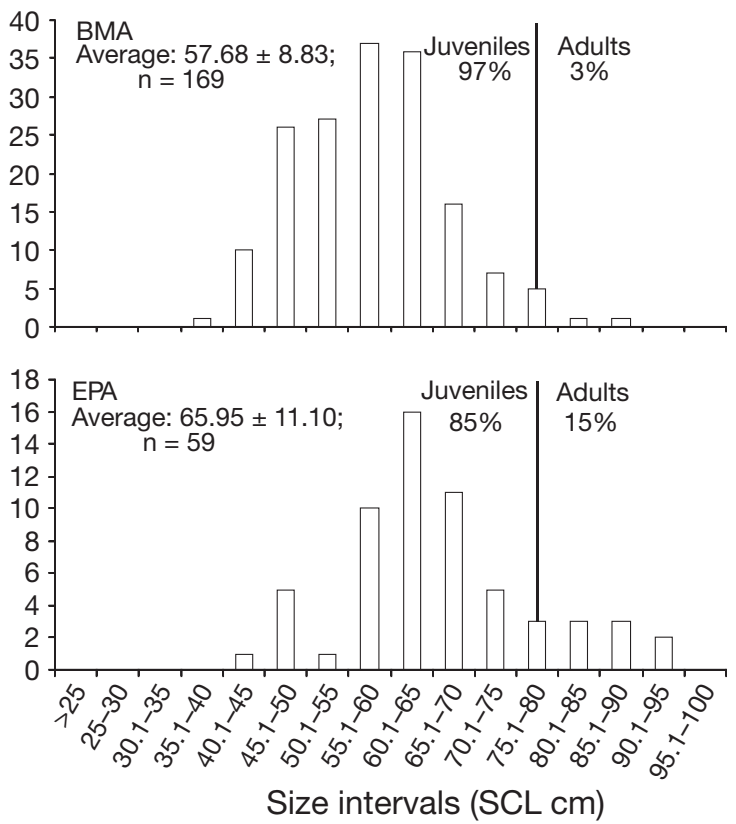

Fig. 2. Chelonia mydas. Size distribution of black turtles at 5 foraging areas off the Baja California Peninsula. Vertical line at $77 \mathrm{~cm}$ SCL indicates approximate size at maturity. Average size and standard deviation are given, as well as percentage of juvenile and adult specimens. LOL: Laguna Ojo de Liebre; PAO: Punta Abreojos; LSI: Laguna San Ignacio; BMA: Bahía Magdalena; EPA: El Pardito

$\mathrm{yr}^{-1}$ (a $50.8 \mathrm{~cm}$ SCL turtle at large for $13 \mathrm{mo}$ at LOL). The mean annual growth rate was $2.3 \pm 1.4 \mathrm{~cm} \mathrm{yr}^{-1}$; it was lowest at BMA $\left(1.4 \pm 0.7 \mathrm{~cm} \mathrm{yr}^{-1}\right)$ and highest at LOL $\left(3.1 \pm 2.2 \mathrm{~cm} \mathrm{yr}^{-1}\right)$. PAO and LSI presented similar rates $\left(2.4 \pm 1.2\right.$ and $2.1 \pm 1.3 \mathrm{~cm} \mathrm{yr}^{-1}$, respectively) (Fig. 4). ANOVA, however, showed that only the annual growth rate at BMA was significantly different from that at other sites (Table 5). Growth rates amongst different size classes (initial SCL) were not significantly different $(F=0.3524, \mathrm{df}=7, \mathrm{p}=0.9267)$

Table 2. Chelonia mydas. Black turtle morphometric data measured at each site during the 5 yr of monitoring off the Baja California Peninsula. SCL: straight carapace length; BCI: body condition index. LOL: Laguna Ojo de Liebre; PAO: Punta Abreojos; LSI: Laguna San Ignacio; BMA: Bahia Magdalena; EPA: El Pardito

\begin{tabular}{|c|c|c|c|c|c|c|c|c|c|c|c|c|}
\hline \multirow[t]{2}{*}{ Site } & \multicolumn{4}{|c|}{$-\operatorname{SCL}(\mathrm{cm})-$} & \multicolumn{4}{|c|}{ - Mass $(\mathrm{kg})$} & \multirow[b]{2}{*}{$\mathrm{n}$} & $\mathrm{BCI}$ & \multirow{2}{*}{ Mean } & \multirow[b]{2}{*}{$\mathrm{SD}$} \\
\hline & $\mathrm{n}$ & Range & Mean & $\mathrm{SD}$ & $\mathrm{n}$ & Range & Mean & $\mathrm{SD}$ & & Range & & \\
\hline LOL & 143 & $38.5-88.8$ & 59.7 & 10.4 & 143 & $9.1-99.8$ & 31.9 & 18.0 & 143 & $0.83-2.01$ & 1.32 & 0.16 \\
\hline $\mathrm{PAO}$ & 604 & $32.1-95.5$ & 58.7 & 10.5 & 584 & $7.3-108.9$ & 29.8 & 17.9 & 584 & $0.67-2.30$ & 1.34 & 0.17 \\
\hline LSI & 220 & $38.2-82$ & 52.7 & 7.7 & 218 & $6.8-79.4$ & 20.0 & 10.9 & 218 & $0.80-2.03$ & 1.27 & 0.23 \\
\hline BMA & 169 & $38.8-85.6$ & 57.7 & 8.8 & 165 & $7-80.7$ & 27.2 & 12.9 & 165 & $0.85-1.68$ & 1.32 & 0.15 \\
\hline EPA & 59 & $45-92.1$ & 66.0 & 11.1 & 59 & $12-104$ & 41.8 & 22.4 & 59 & $1.04-1.69$ & 1.38 & 0.13 \\
\hline Total & 1195 & & & & 1169 & & & & 1169 & & & \\
\hline
\end{tabular}


Table 3. Kruskal-Wallis ANOVA comparing straight carapace length (SCL) and mass (M) of black turtles between the 5 monitoring sites in Baja California Sur. Results of the post hoc comparison using the Kruskal-Wallis 2-sample ranking test. Asterisks indicate homogeneous groups a to c. Site abbreviations as defined in Table 2

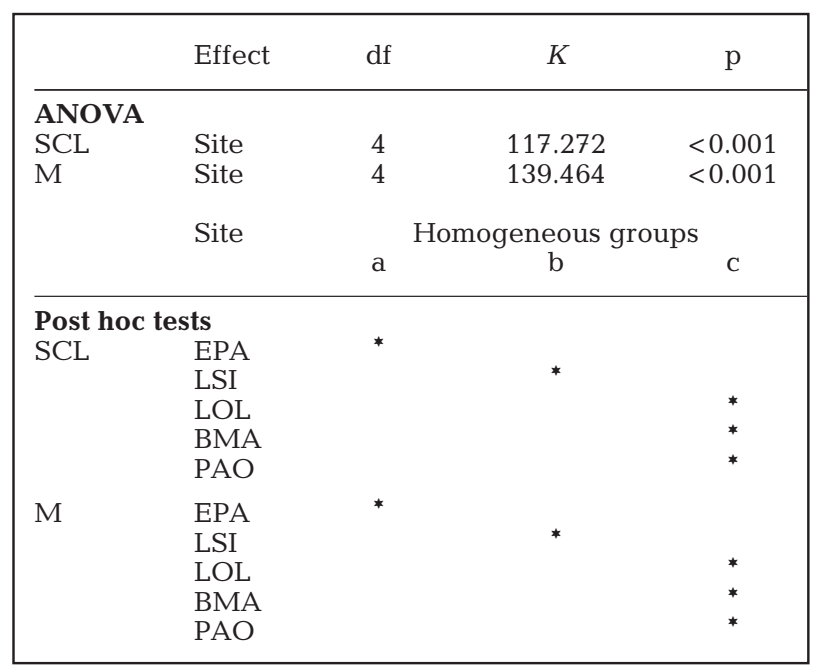

\section{CPUE}

CPUE was analyzed only at 4 sites; EPA was excluded since we only had data for one year (2005). A total of 6309 netting hours yielded 1183 captures of 1029 black turtles from all sites during the 5 yr of monitoring (Table 1). Monthly CPUE at each of the sites varied widely due to weather conditions, tides and time of capture (Fig. 5); therefore, data must be interpreted with caution. In general, CPUE was highest at PAO (mean = 17.35) and lowest at BMA $($ mean = 1.78) throughout the sampling period.

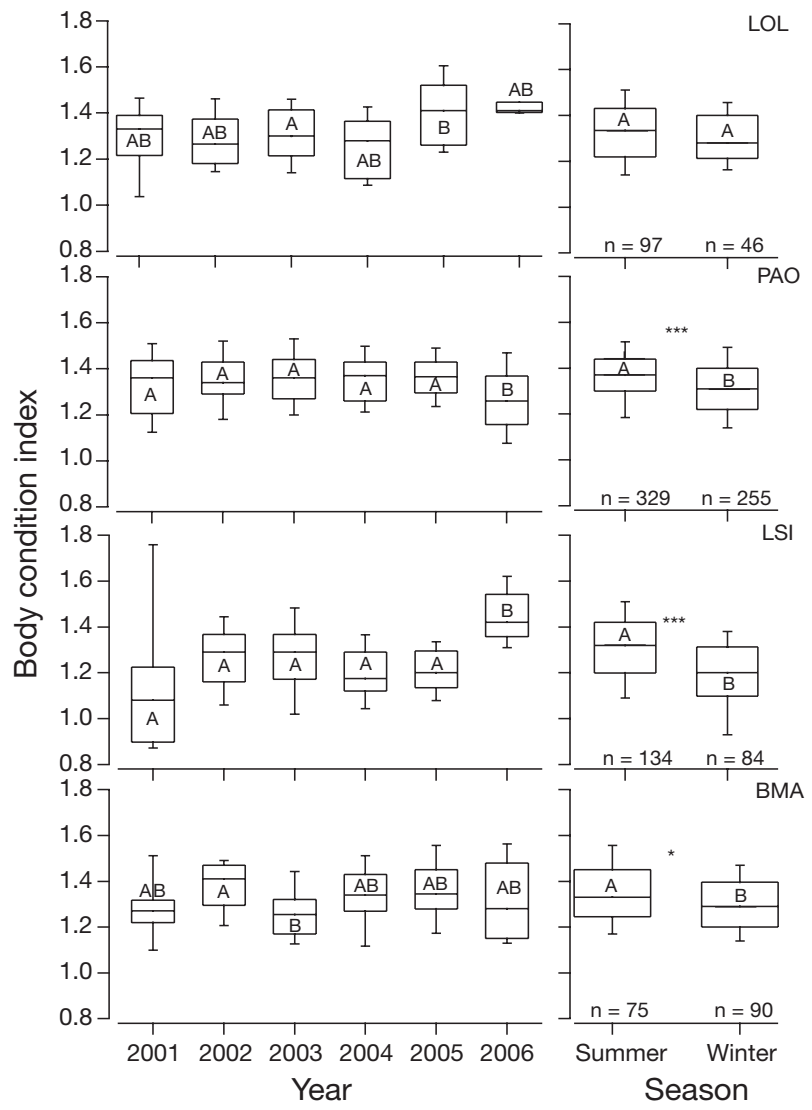

Fig. 3. Chelonia mydas. Body condition index (BCI) of black turtles at 4 sampling sites (site abbreviations as defined in Fig. 2). The first column shows the average BCI over the years, letters denote homogeneous groups according to ANOVA (Table 2) and Tukey's post hoc comparisons. The second column shows seasonal comparisons at the same sites (summer: May to October; winter: November to April). Asterisks indicate significant differences according to 2-tailed $t$-tests. ${ }^{*}: \mathrm{p}<0.05 i^{* *}: \mathrm{p}<0.01 i^{* * *}: \mathrm{p}<0.001$
Table 4. One-way ANOVAs comparing (a) average body condition index (BCI) of black turtles between the 4 monitoring sites of Baja California Sur and (b) comparing BCI between years at each site from 2001 to 2006. Results of Tukey's post hoc comparison are shown in Fig. 3. Site abbreviations as defined in Table 2

\begin{tabular}{|llccccc|}
\hline & Effect & $\mathrm{SS}$ & $\mathrm{df}$ & $\mathrm{MS}$ & $F$ & $\mathrm{p}$ \\
\hline (a) & & & & & & \\
& Site & 1.049 & 4 & 0.2623 & 11.08 & $<0.001$ \\
& Error & 27.86 & 1177 & 0.02367 & & $\mathrm{p}$ \\
\hline \hline Site & Effect & $\mathrm{SS}$ & $\mathrm{df}$ & $\mathrm{MS}$ & $F$ & \\
\hline (b) & & & & & & \\
LOL & Year & 0.3784 & 5 & 0.07568 & 2.672 & 0.024 \\
& Error & 3.937 & 139 & 0.02832 & & \\
PAO & Year & 0.6691 & 5 & 0.1338 & 6.475 & $<0.0001$ \\
& Error & 11.99 & 580 & 0.02067 & & \\
LSI & Year & 1.181 & 5 & 0.2362 & 7.257 & $<0.0001$ \\
& Error & 6.964 & 214 & 0.03254 & & \\
BMA & Year & 0.3445 & 5 & 0.0689 & 3.447 & 0.006 \\
& Error & 3.218 & 161 & 0.01999 & & \\
\hline
\end{tabular}

\section{DISCUSSION}

In-water sea turtle monitoring is not an easy task. Besides high costs and complicated logistics, it depends largely on weather conditions, site selection, characteristics of the area and experience of the participants. While studying different foraging areas along the Baja California Peninsula is a great opportunity to collect valuable information about black turtles, there are also inherent difficulties related to the standardization of capture techniques and data collection. For instance, all sites differed in area (size) and oceanographic conditions, 


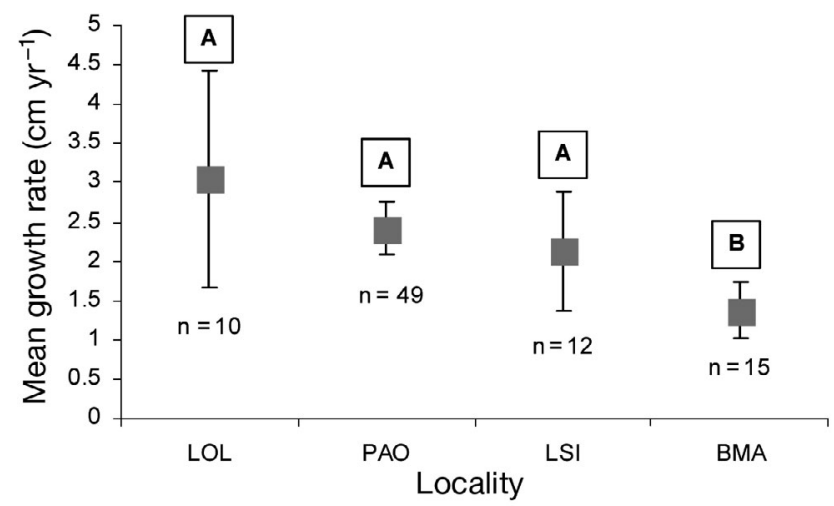

Fig. 4. Chelonia mydas. Mean annual growth rate (error bars: $95 \%$ confidence intervals) of black sea turtles by site (site abbreviations as defined in Fig. 2). Letters denote homogeneous groups as defined by ANOVA and Tukey's post hoc comparisons

Table 5. One-way ANOVA comparing annual growth rate of black turtles between 4 monitoring sites in Baja California Sur (LOL, PAO, LSI, BMA; abbreviations as defined in Table 2). Results of Tukey's post hoc comparison are shown in Fig. 4

\begin{tabular}{|lccccc|}
\hline Effect & SS & df & MS & $F$ & $p$ \\
\hline Site & 19.435 & 3 & 6.4785 & 3.7973 & 0.0132 \\
Error & 139.899 & 82 & 1.7060 & & \\
\hline
\end{tabular}

which led to the use of different net dimensions, a reduction in monitoring time (between 12 and $24 \mathrm{~h}$ ) and different net placement within each water body (closer to the mouth of the lagoons or across channels in the inner lagoon). All these factors influenced the CPUE and must be considered when interpreting our results.

\section{Size-frequency distribution}

Several authors have mentioned that juvenile black turtles in the eastern Pacific Ocean shift from an oceanic to a neritic phase at 35 to $40 \mathrm{~cm} \mathrm{SCL}$ (Seminoff 2000, Seminoff et al. 2002, Nichols 2003, López-Mendilaharsu et al. 2005). However, these same authors have mentioned that is rare to see turtles smaller than $46 \mathrm{~cm}$ SCL in nearshore areas of the Baja California Peninsula like Bahía de Los Angeles and Bahía Magdalena. In the present study, sizes from 30 to $46 \mathrm{~cm}$ SCL were recorded at 4 of 5 study sites. This is not unexpected, as most of the monitoring teams worked in protected, shallow waters inside coastal lagoons where small turtles tend to aggregate (Koch et al. 2007). In other regions of the Pacific, black turtles recruit to foraging areas at around $35 \mathrm{~cm}$ SCL (Balazs \& Chaloupka 2004), similar to the size we obtained.
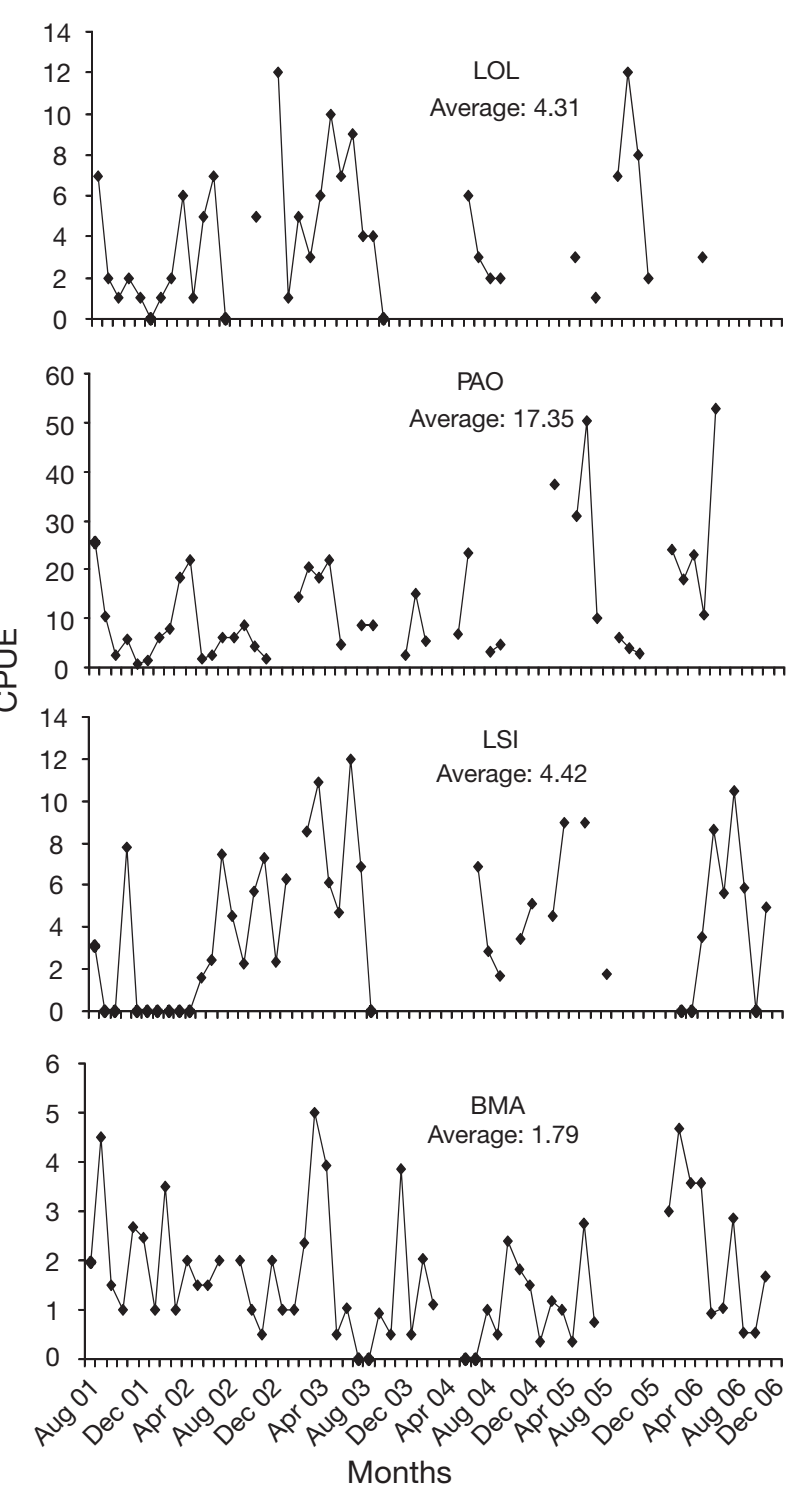

Fig. 5. Chelonia mydas. Monthly catch per unit effort (CPUE) from August 2001 to December 2006 at 4 foraging areas off the Baja California Peninsula (site abbreviations as defined in Fig. 2). Gaps reflect months where monitoring was not conducted. Note the scale difference on the $y$-axes

In general, juvenile turtles accounted for more than $90 \%$ of the turtles in the 5 foraging areas. The smallest mean SCL at LSI can be explained by the fact that the monitoring site was located in the innermost part of the lagoon. According to Koch et al. (2007), segregation by size within foraging areas does occur, with smaller turtles inhabiting the inner, more protected waters and larger juveniles and adults residing farther out in deeper, less protected waters. Larger juveniles and adult turtles were most abundant at EPA, which may be due to a higher percentage of adult turtles staying in the Gulf of California on their way back to northern 
foraging grounds after the reproductive season (Seminoff et al. 2003). On the other hand, the large area of rocky outer coast in the Gulf of California could also explain the presence of a higher proportion of adults, as it is less protected than the coastal lagoon systems on the Pacific coast and thus potentially more suitable for larger turtles.

\section{Body condition index}

The mean BCI of turtles at the 5 sites was not very different from year to year (usually between 1.2 and 1.4, except for Year 5 at LSI). Compared to earlier work on the Baja California Peninsula, BCI was similar to that reported by Seminoff et al. (2003) of $1.42 \pm$ 0.015 in the Gulf of California and Koch et al. (2007) of $1.62 \pm 0.348$ in the Pacific (BMA), but higher than that reported by Caldwell (1962) of $1.21 \pm 0.023$ for black turtles in the Gulf of California. BCI were also generally higher than values reported by Bjorndal et al. (2000) for Caribbean green turtles, except for one year when there was an exceptionally low turtle abundance. After the population crash between the 1950s and the 1970s, nesting numbers of black turtles decreased by over $95 \%$ in the eastern Pacific (Cliffton et al. 1982, Alvarado-Diaz et al. 2001). Since that time, food abundance should not have been a limiting factor for black turtles in Baja California, as numbers on their coastal feeding grounds should have stayed well below carrying capacity of the environment. This could also explain the lower BCI values reported by Caldwell (1962) in the early 1960s, as sea turtle abundance was still an order of magnitude greater than today. However, further studies on the carrying capacity of the foraging areas on the Baja California Peninsula need to be conducted to address this question. It is interesting to note that black turtles at PAO, the site with by far the highest CPUE and turtle abundance, had BCI values no lower than those from other sites. It seems they are well fed, which implies that historic population numbers may have been even greater, assuming that food availability would be reflected in decreasing $\mathrm{BCI}$ as population numbers reach carrying capacity. Few historic data exist, but Townsend (1916) reported that a single haul from a $200 \mathrm{~m}$ long seine net in Bahía Tortugas, Baja California, brought in 162 turtles, and many more escaped during the operation, indicating a very high population density.

The seasonal differences in BCI can probably be explained by temperature and food availability (Koch et al. 2007). Winter temperatures below 18 to $20^{\circ} \mathrm{C}$ make turtles sluggish; they forage less (Moon et al. 1997) and they may hibernate (Felger et al. 1976). Food productivity and abundance are also much lower during the winter months in Bahía Magdalena (Gonzalez Ramos \& Santos Baca 2005), and possibly so in the other lagoons, although this has not been studied to date.

The comparatively high BCI and very few incidences of sick turtles (as inferred from external observations of parasites, tumors, lesions and lack of a 'healthy' appearance) suggests that foraging areas in the Baja California Peninsula still contain comparatively clean water; the low human population density results in less contamination (Aguirre \& Lutz 2004). This is in contrast to other areas in the Pacific such as Hawaii (Balazs \& Chaloupka 2004), California (MacDonald \& Dutton 1990) and Australia (Limpus \& Miller 1990, Raidal \& Prince 1996), where in some cases high infection rates with fibropapilloma have been reported.

\section{Annual growth rate}

Few data exist on annual growth rate of black turtles in the eastern Pacific. The most recent study was conducted by Koch et al. (2007), who estimated a mean annual growth rate of $1.62 \mathrm{~cm} \mathrm{yr}^{-1}$ at BMA for black turtles ranging from 45 to $67 \mathrm{~cm}$ SCL, taking into account seasonal growth rate variations. Koch et al. (2007) used a larger database of BMA turtles (without considering other sites), including those caught by the School for Field Studies from 2000 onwards, explaining the slight difference to the growth rate found in the present study $\left(1.4 \pm 0.7 \mathrm{~cm} \mathrm{yr}^{-1}\right)$. Black turtles from the other 3 sites (LOL, LSI and PAO) grew faster, which could have been caused by many factors including food abundance and quality, population density, site selection, age, sex, water temperature and health status (Bjorndal et al. 2000, Seminoff et al. 2002). To understand which combination of these factors caused the observed differences, more in-depth studies on the feeding ecology of black turtles at different sites are necessary. One possible factor is the proportion of animal matter in the diet (though black turtles are mainly herbivorous, they can rely on animal sources for food), as a higher consumption of animal protein could account for the observed differences in growth (Wood \& Wood 1981, Amorocho \& Reina 2007, P. Dutton pers. comm.).

Considering that the Mexican black turtle nesting population declined by $95 \%$ from 1970 to the late 1990s (Alvarado-Diaz et al. 2001), it is hard to believe that resource limitation due to high densities of turtles could be affecting growth. However, human impact has grown, especially in the past 2 decades, possibly affecting abundance and quality of food resources for black turtles. Other anthropogenic causes could be 
habitat loss and contamination, both of which can reduce the health status of a population (Gardner et al. 2003, 2006). Low quality and abundance of food might also negatively influence the annual growth rate of black turtles (Villegas-Nava 2006). Thus, while density of sea turtles (and resource competition among individuals) in this area must have been much greater in the past (according to the total sea turtle catch in this region during the 1970s; Márquez \& Doi 1973, Márquez et al. 1982, Márquez 1990), the carrying capacity of the environment may have changed over time.

Though considerable regional variability in growth rates of black turtles in the eastern Pacific has been found (Seminoff et al. 2002), the case of black turtles at BMA is intriguing; the BCI $(1.32 \pm 0.14)$ is similar to that for other sites (except LSI), suggesting that resource availability for individual turtles is comparable among sites. However, the mean annual growth rate of $1.4 \mathrm{~cm} \mathrm{yr}^{-1}$ is low compared to the other sites, suggesting that food quality, quantity or some other resource differs in comparison to the other sampling sites. It is interesting to note that BMA is the only site on the Pacific coast that is not protected, the other 3 sites form part of the El Vizcaino Biosphere reserve. Clearly, more studies on the abundance and composition of food resources and diet analysis at the different foraging areas are needed to help answer this question.

\section{CPUE}

Our CPUE data must be interpreted with care. It is unlikely that capture probabilities are the same at the 4 sites, and they have possibly changed over time. We do not know if turtles learn to avoid the net, and while we had a lot of recaptures, we cannot rule out a bias in our results caused by net avoidance. A thorough markrecapture analysis is really the only way to quantitatively compare sea turtle abundance among sites and over time (Anderson 2001, Pollock et al. 2002), but as the number of recaptures is relatively low, we need more years of data to provide trustworthy results.

The high monthly variations in CPUE can be attributed to factors such as currents, weather and season. However, there is a striking difference in mean annual CPUE among the 4 sites studied from 2001. CPUE at PAO was 4 to 10 times higher than at the other sites. It is possible that this is a reflection of better protection at $\mathrm{PAO}$, since fishing is strictly regulated in Estero Coyote where the monitoring took place. Illegal capture of turtles still exists in the area and around 40 to 50 carapaces of recently dead turtles were found in 2007 (Mancini 2009, Mancini \&
Koch 2009). At the other sites, however, fishing is less regulated and mortality through incidental capture and poaching is higher (Koch et al. 2006, Mancini 2009, Mancini \& Koch 2009). This may also explain why CPUE at BMA is the lowest of all 4 sites: it is the most important fishing ground in the state, but regulation of fisheries is still virtually nonexistent, resulting in high incidental capture of sea turtles. Additionally, there is significant mortality caused by illegal capture for consumption (Gardner \& Nichols 2001, Koch et al. 2006, Peckham \& Nichols 2006, Peckham et al. 2008).

\section{Recapture of individuals and conservation implications}

Although some of the foraging areas in the Pacific are relatively close (LSI and PAO are only approx. $40 \mathrm{~km}$ apart), we did not observe individuals marked in one area that were later recaptured at another site. Until now (after 10 yr of monthly monitoring in distinct foraging areas of the Baja California Peninsula and almost 2000 captures as of mid-2009), we know of only 2 ind. that have been tagged in one foraging area and captured in another (Senko et al. 2010). This indicates that there is low connectivity among the foraging areas of the Baja California Peninsula and is in accordance with Aguirre \& Lutz (2004) and Koch et al. (2007), who found that young turtles show high fidelity to their coastal feeding habitats. While we cannot rule out the possibility that approximately 1000 marked turtles are not enough under the current effort regime to detect migrants, we believe that strengthening local protection is imperative to ensure that more turtles reach maturity and reproduce in order to recover sea turtle populations (Koch et al. 2007).

Acknowledgements. The authors thank Secretaría del Medio Ambiente y Recursos Naturales and Instituto Nacional de Ecología for permits granted. B. Bermudez helped with the permits at the Reserva de la Biosfera del Vizcaino sites. ProPeninsula provided logistical support and National Marine Fisheries Service provided funding for sea turtle monitoring efforts. Staff at the School for Field Studies at Puerto San Carlos helped in the collection of data at BMA. Grupo Tortuguero coordinators J. Lucero, R. Rangel and F. J. Villavicencio Ojeda are thanked for their invaluable help in the coordination of monitoring teams and data collection. We thank the following Grupo Tortuguero monitoring team members: M. Valenzuela Zuñiga, E. Patrón de la Toba, I. Arce Arce and F. J. Villavicencio Ojeda (PAO); J. C. Solis Hernandez, J. M. Aguirre Ozuna and R. A. Villegas (BMA); R. Mayoral Aguilar and F. J. Fisher Murillo (LSI); H. Toledo Reza, G. Z. Aguilar, R. Zaragoza Aguilar, M. García Aguilar and F. Castillo Romero (LOL); F. Cuevas Amador, P. Cuevas Collins, I. Cuevas Collins, J. Salvador Aceves, F. Cuevas Collins and A. Esliman (EPA). 


\section{LITERATURE CITED}

Águila-Ramírez RN (1998) Variación estacional de la distribución de las microalgas en la Laguna Ojo de Liebre, B.C.S. MS thesis, IPN-CICIMAR, La Paz, Baja California Sur

Aguirre AA, Lutz PL (2004) Marine turtles as sentinels of ecosystem health: Is fibropapillomatosis an indicator? EcoHealth 1:275-283

Alvarado-Diaz J, Delgado-Trejo C, Suazo-Ortuno I (2001) Evaluation of the black turtle project in Michoacán, Mexico. Mar Turtle Newsl 92:4-7

Amorocho DF, Reina RD (2007) Feeding ecology of the East Pacific green sea turtle Chelonia mydas agassizii at Gorgona National Park, Colombia. Endang Species Res 3: 43-51

Anderson DR (2001) The need to get the basics right in wildlife field studies. Wildl Soc Bull 29(4):1294-1297

Balazs GH, Chaloupka M (2004) Spatial and temporal variability in somatic growth of green sea turtles (Chelonia mydas) resident in the Hawaiian Archipelago. Mar Biol 145:1043-1059

Bjorndal KA, Bolten AB, Chaloupka MY (2000) Green turtle somatic growth model: evidence for density dependence. Ecol Appl 10:269-282

Caldwell DK (1962) Carapace length-body weight relationship and size and sex ratio of the Northeastern Pacific green turtle, Chelonia mydas carrinegra. Contrib Sci 62:3-10

Chaloupka MY, Musick JA (1997) Age, growth, and populations dynamics. In: Lutz PL, Musick JA (eds) The biology of sea turtles. CRC Press, Boca Raton, FL, p 223-276

Cliffton K, Cornejo DO, Felger RS (1982) Sea turtles of the Pacific coast of Mexico. In: Bjorndal KA (ed) Biology and conservation of sea turtles. Smithsonian Institution Press, Washington, DC, p 199-209

Delgado S, Nichols WJ (2005) Saving sea turtles from the ground up: awakening sea turtle conservation in northwestern Mexico. MAST Marit Anthropol Stud 3/4:89-104

Diario Oficial de la Federación (1990) Acuerdo que establece veda para todas las especies y subespecies de tortugas marinas en aguas de jurisdicción nacional de los litorales del océano Pacífico, Golfo de Mexico y Mar Caribe. p 21-22, http://dof.gob.mx/

Esquivel Bobadilla S (2007) Identificación de las poblaciones de origen de las tortugas prietas muestreadas en Bahía Magdalena, B.C.S., Mexico (1995-2005). BS thesis, Universidad Autónoma de Baja California Sur, La Paz

Felger RS, Cliffton K, Regal PJ (1976) Winter dormancy in sea turtles: independent discovery and exploitation in the Gulf of California, Mexico by two local cultures. Science 191:283-285

Gardner SC, Nichols WJ (2001) Assessment of sea turtle mortality rates in the Bahía Magdalena region, B.C.S, Mexico. Chelonian Conserv Biol 4:197-199

Gardner SC, Pier MD, Wesselman R, Juárez A (2003) Organochlorine contaminants in sea turtles from the eastern Pacific. Mar Pollut Bull 46:1082-1089

Gardner SC, Fitzgerald SL, Acosta-Vargas B, MéndezRodríguez L (2006) Heavy metal accumulation in four species of sea turtles from the Baja California Peninsula, Mexico. Biometals 19:91-99

Gonzalez-Ramos MS, Santos-Baca L (2005) Macroalgas asociadas a la zona de alimentación de la tortuga verde del Pacífico este (Chelonia mydas agassizii) en el Estero Banderitas, BCS. Parte I: variación espacial y temporal de la estructura de la comunidad. Parte II: Estructura poblacional y tendencias reproductivas. BS thesis, Universidad Autónoma de Baja California Sur, La Paz

Groombridge B, Luxmoore R (1989) The green turtle and hawksbill (Reptilia: Cheloniidae): world status, exploita- tion and trade. United Nations Environment Programme, Cambridge

Grubbs F (1969) Procedures for detecting outlying observations in samples. Technometrics 11:1-21

Hilton-Taylor C (2000) IUCN Red List of threatened species. IUCN, Gland

Koch V, Nichols WJ, Brooks LB, Gardner SC (2002) Black turtle (Chelonia mydas) mortality in Bahía Magdalena, Baja California Sur, Mexico. In: Proceedings of the 22nd Annual Symposium on Sea Turtle Biology and Conservation, Miami, FL, p 83

Koch V, Nichols WJ, Peckham H, de la Toba V (2006) Estimates of sea turtle mortality from poaching and bycatch in Bahía Magdalena, Baja California Sur, Mexico. Biol Conserv 128:327-334

Koch V, Brooks LB, Nichols WJ (2007) Population ecology of the green/black turtle (Chelonia mydas) in Bahia Magdalena, Mexico. Mar Biol 153:35-46

Limpus CJ, Miller JD (1990) The occurrence of cutaneous fibropapillomas in marine turtles in Queensland. In: R. James (ed) Proceedings of the Australian Marine Turtle Conservation Workshop. Queensland Department of Environment and Heritage and Australian Nature Conservation Agency, Brisbane, $\mathrm{p} 86$

Lluch-Belda D, Hernández-Rivas ME, Saldierna-Martínez R, Guerrero-Caballero R (2000) Variabilidad de la temperatura superficial del mar en Bahía Magdalena, B.C.S. Oceanides 15:1-23

López-Mendilaharsu M, Gardner SC, Seminoff JA, Riosmena-Rodríguez R (2005) Identifying critical foraging habitats of the green turtle (Chelonia mydas) along the Pacific coast of the Baja California peninsula, Mexico. Aquat Conserv 15:259-269

MacDonald D, Dutton P (1990) Fibropapillomas on sea turtles in San Diego Bay, California. Mar Turtle Newsl 51:9-10

Maeda-Martínez EN, Reynoso T, Solis F, Leija A, Aureoles D, Salinas C, Lluch-Cota D, Ormat P (1993) A model to explain the formation of catarina scallop Argopecten circularis (Sowerby 1835) beds in Magdalena Bay, Mexico. Aquac Fish Manage 24:323-339

Mancini A (2009) Incidental bycatch or directed harvest? Mortality rates of sea turtle in Baja California Sur. PhD thesis, Universidad Autónoma de Baja California Sur, La Paz

Mancini A, Koch V (2009) Sea turtle consumption and black market trade in Baja California Sur, Mexico. Endang Species Res 7:1-10

Márquez R (1990) FAO species catalogue. Vol 11. Sea turtles of the world. An annotated and illustrated catalogue of sea turtles known to date. FAO, Rome

Márquez R, Doi T (1973) A trial of theoretical analysis on population of Pacific green sea turtle Chelonia mydas carrinegra Caldwell, in waters of the Gulf of California, Mexico. Bull Tokai Reg Fish Res Lab 73:1-22

Márquez R, Peñaflores CS, Villanueva AO, Díaz JF (1982) A model for diagnosis of populations of olive ridleys and green turtles of west Pacific tropical coasts. In: Bjorndal KA (ed) Biology and conservation of sea turtles. Smithsonian Institution Press, Washington, DC, p 153-158

Moon DY, MacKenzie DS, Owens DW (1997) Simulated hibernation of sea turtles in the laboratory: I. Feeding, breathing frequency, blood $\mathrm{pH}$ and blood gases. J Exp Zool 278:372-380

Nichols WJ (2003) Biology and conservation of sea turtles in Baja California, Mexico. PhD dissertation, University of Arizona, Tucson

Peckham SH, Nichols WJ (2006) An integrated approach to reducing mortality of North Pacific loggerhead turtles in 
Baja California Sur, Mexico. In: Kinan I (ed) Proceedings of the Second Western Pacific Sea Turtle Cooperative Research and Management Workshop. Volume II: North Pacific Loggerhead Sea Turtles. 2-3 Mar 2005, Honolulu, HI. Western Pacific Regional Fishery Management Council, Honolulu, HI, p 49-57

Peckham SH, Maldonado D, Koch V, Mancini A, Gaos A, Nichols WJ (2008) High mortality of loggerhead turtles due to bycatch, human consumption and strandings at Baja California Sur, Mexico, 2003 to 2007. Endang Spec Res 5:171-183

Pollock KH, Nichols JD, Simons TR, Farnsworth GL, Bailey LL, Sauer JR (2002) Large scale wildlife monitoring studies: statistical methods for design and analysis. Environmetrics 13:105-119

Raidal SR, Prince RIT (1996) First confirmation of multiple fibropapillomas in a western Australian green turtle (Chelonia mydas). Mar Turtle Newsl 74:7-9

Rengstorf A (2007) Comparative growth and mortality of cultured lion's paw scallops (Nodipecten subnodosus) from Gulf and Pacific populations and their reciprocal transplants in B.C.S., Mexico. MS thesis, University of Bremen

Seminoff JA (2000) Biology of the east Pacific green turtle, Chelonia mydas agassizii, at a warm temperate feeding area in the Gulf of California, Mexico. PhD thesis, University of Arizona, Tucson

Editorial responsibility: Matthew Godfrey, Beaufort, North Carolina, USA
Seminoff JA, Resendiz A, Nichols WJ, Jones TT (2002) Growth rates of wild green turtles (Chelonia mydas) at a temperate foraging area in the Gulf of California, Mexico. Copeia 610-617

- Seminoff JA, Jones TT, Resendiz A, Nichols WJ, Chaloupka MY (2003) Monitoring green turtles (Chelonia mydas) at a coastal foraging area in Baja California, Mexico: multiple indices describe population status. J Mar Biol Assoc UK 83:1355-1362

Senko J, López-Castro MC, Koch V, Nichols WJ (2010) Immature east Pacific green turtles (Chelonia mydas) use multiple foraging areas off the Pacific coast of Baja California Sur, Mexico: first evidence from mark-recapture data. Pac Sci 64:125-130 doi:10.2984/64.1.125

Townsend CH (1916) Voyage of the Albatross to the Gulf of California in 1911. Bull Am Mus Nat Hist 31:117-130

Villegas-Nava FE (2006) Análisis nutricional de macroalgas y pastos asociados a la alimentación de tortuga prieta Chelonia mydas agassizii (Bocourt, 1968), en Bahía Magdalena, B.C.S., Mexico. Tesis de Licenciatura. Universidad Autónoma de Baja California Sur, La Paz

Wood JA, Wood FE (1981) Growth and digestibility for the green turtle (Chelonia mydas) fed diets containing varying protein levels. Aquaculture 25:269-274

Zar JH (1999) Biostatistical analysis, 4th edn. Prentice Hall, Upper Saddle River, NJ

Submitted: August 18, 2008; Accepted: December 7, 2009 Proofs received from author(s): March 2, 2010 